\title{
ОБЗОРНИ СТАТИИ
} REVIEW ARTICLES

\author{
ТЕРАПЕВТИЧНИЯТ ПОТЕНЦИАЛ НА КУРКУМИНА \\ Калоян Калоянов ${ }^{1}$, Мая Йотова $^{2}$, Георги Момеков ${ }^{1}$, Спиро Константинов \\ ${ }^{1}$ Катедра по фармакология, токсикология и фармакотерапия, Фармачевтичен факултет, МУ-София \\ ${ }^{2}$ Медицински колеж, МУ-Плевен
}

CURCUMIN'S THERAPEUTIC POTENTIAL

Kaloyan Kaloyanov', Maya Yotova ${ }^{2}$, Georgi Momekov ${ }^{1}$, Spiro Konstantinov ${ }^{1}$

${ }^{1}$ Department of Pharmacology, Toxicology and Pharmacotherapy, Faculty of Pharmacy, MU-Sofia

${ }^{2}$ Medical College, MU-Pleven

\begin{abstract}
PEЗЮME
Куркумата (Curcuma longa L., сем. Zingiberaceae) е подправка, която е широко използвана в индийската медицина. В спектъра на заболяванията, при които намира приложение, влизат жлъчни и чернодробни заболявания, безапетитие, синузит, ревматизъм, навяхвания и рани. Основното биологично активно вещество в корена от куркума е куркуминът, съпътствано от други близкородствени съединения. За терапевтичния потенциал на куркумина има редица данни от експериментални изследвания, както и клинични данни. Многобройни проучвания показват, че той има значителна противотуморна и в частност противомиеломна активност и откриват перспектива за бъдещото му приложение като лекарствен продукт. Лабилността му при орално приложение, както и потенциалните лекарствени взаимодействия с различни медикаменти, ограничават неговото свободно приложение под формата на капсулни и таблетни форми, но приемът му като подправка е показал само и единствено ползи за употребяващите го.
\end{abstract}

Ключови думи: куркумин, миелом

\begin{abstract}
Turmeric (Curcuma longa L., Zingiberaceae) is a spice that is widely used in Indian medicine. The spectrum of diseases in which it is applied includes bile and liver diseases, dizziness, sinusitis, rheumatism, sprains and wounds. The main biologically active substance in the turmeric root is curcumin, accompanied by other closely related compounds. For the therapeutic value of curcumin, there are a number of data from experimental studies as well as clinical data. Numerous studies have shown that it has significant anti-tumor and, in particular, anti-myeloma activity, and have discovered prospects for its future use as a medicinal product. Its lability in oral administration as well as potential drug interactions with various drugs restrict its free use in the form of capsule and tablet formulations, but its administration as a spice has only shown benefits to the patients.
\end{abstract}

Keywords: curcumin, myeloma 


\section{ВЪВЕДЕНИЕ}

Куркумата(CurcumalongaL., сем.Zingiberaceae), освен като подправка, се използва и като лечебно растение в индийската народна медицина вече повече от 5000 години (Perrone et al. 2015). В спектьра на заболяванията, при които намира приложение, влизат жльчни и чернодробни заболявания, безапетитие, синузит, ревматизьм, навяхвания и рани. През 1815 г. от коренището на растението е изолирано веществото куркумин, идентифицирано по-късно като диферулоилметан и причислено към групата на полифенолните съединения. В дрогата Curcumae Rhizoma са установени и други близкородствени на куркуминасъединения. Товасадезметоксикуркумин (куркумин II), бисдезметоксикуркумин (куркумин III) и циклокуркумин (Goel et al., 2008). Тези вещества и куркуминьт се наричат общо куркуминоиди и съставляват 3-5\% от сухото тегло на коренището. Добиват се чрез алкохолна екстракция. В търговски предлагания на куркумин се съдържат главно куркумин I ( $\sim 77 \%)$, куркумин II ( $\sim 7 \%$ ) и куркумин III $(\sim 3 \%)$. Чистият куркумин представлява жълтооранжев прах, лошо разтворим във вода и етер, добре разтворим в етанол, диметилсулфоксид и ацетон (Goel et al., 2008, Perrone et al., 2015). Алкохолният разтвор има ярко жълт цвят при рН между 2,5 и 7 и червен цвят при $\mathrm{pH}>7$. В разтвор претьрпява кетоенолна тавтомерия, като равновесието е изтеглено в посока към енолната форма. Куркуминът е стабилен в кисела среда, но в неутрална или алкална среда бързо се разгражда до ферулова киселина и ферулоилметан. Във фосфатен буфер с $\mathrm{pH}$ 7,2 само за 30 минути куркуминът се разгражда почти напълно. Антиоксидантите обаче забавят този процес.

Експериментални данни за куркумина и повлияваните от него сигнални каскади

Куркуминът има сложен и многостранен механизъм на действие. Той може да взаимодейства прякосмного мишени вклетката, коитоотсвоястрана повлияват различни сигнални пьтища. Куркуминът инхибира киназния комплекс IKK и така пречи на активирането на NF-кB (Perrone et al., 2015). Куркуминът пряко инхибира каталитичната активност на 20S-компонента на протеазомата (Gomez-Bougie et al., 2015). Сред другите му мишени влизат: Р-gp, MRP1, MRP2, глутатион, протаминкинази, ErbB2/ HER2, тиоредоксинредуктазата, ксантиноксидаза,

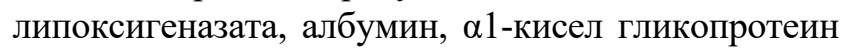
и метални йони като $\mathrm{Fe}^{2+}, \mathrm{Cu}^{2+}$ и $\mathrm{Zn}^{2+}$ (Perrone $\mathrm{D}$ et al., 2015). Инхибирайки IKK, куркуминът възпрепятства фосфорилирането и последващото протеазомно разграждане на IкB $\alpha$. Освен това куркуминът пряко инхибира протеазомата. Така IкB $\alpha$ ce натрупва в цитозола, блокира транслокацията на транскрипционния фактор NF$\kappa \mathrm{B}$ в ядрото и се потиска транскрипцията на голям брой онкогени. Сред тях влизат гените за синтез на PI3K, Akt, ERK, c-Jun, c-Fos, c-Myc, циклини и циклин-зависими кинази, СОХ-2, IAP-1, IAP-2, XIAP, Bcl-2, Bcl-XL и сурвивин (Perrone D et al., 2015). Куркуминът потиска фосфорилирането и ядрената транслокация на различни транскрипционни фактори от семейството STAT, в зависимост от типа на клетките (Ravindran et al., 2009). Особено характерно е инхибирането на STAT3 и последващо индуциране на апоптоза при малигнени плазмоцити. Инхибирайки киназата JNK, куркуминът възпрепятства активирането на транскрипционния фактор АР-1. Куркуминът потиска активирането и на транскрипционните фактори $\beta$-катенин и Egr1 (Perrone et al., 2015; Gomez-Bougie et al., 2015). Потиска още тирозинкиназната активност на EGFR (рецептора за епидермален растежен фактор) (Goel et al., 2008). Куркуминьт стимулира раграждането на Erb-B2/HER2 и нарушава тирозинкиназната му активност. Установено е, че куркуминът понижава активността на сигналния път PI3K/Akt при клетки, произхождащи от карцином на простатата, малигнен глиом или Т-клетъчна левкемия. Куркуминът, в зависимост от типа на клетките, може да стимулира или потиска предаването на сигнали през ERK, JNK и/или p38 (Perrone et al., 2015; Ravindran et al., 2009). Може да действа както като антиоксидант, така и като прооксидант (Ravindra et al., 2009). Конкретните ефекти зависят от концентрацията му, вида на клетките и други фактори, напр. наличие на метални йони. Така например ниски концентрации куркумин защитават хепатоцитите от оксидативен стрес като неутрализират свободните радикали и намаляват липидната пероксидация и освобождаването на цитохром С. Високи концентрации предизвикват изчерпване на глутатиона, активиране на каспаза-3 и апоптоза. При много изследвания след приложение на куркумин е наблюдавана свръхпродукция на реактивни кислородни радикали и индукция на апоптоза при туморни, но не и при нормални клетки. Прооксидантните свойства се обясняват с инхибиране на ензима орнитиндекарбоксилаза и необратимо модифициране на ензима тиоредоксинредуктаза, превръщащо го от антиоксидантен в прооксидантен (Perrone et al., 2015). Тиоредоксинредуктазатаесврьхекспресирана при много тумори, вероятно като механизъм за справяне с по-високия оксидативен стрес, на който 
по принцип са изложени туморните клетки. В зависимост от вида на клетките куркуминът може да индуцира апоптоза предимно чрез външния или предимно чрез вътрешния път. При клетки от белодробен карцином е наблюдавано увреждане на ДНК, индуциране на ЕПР-стрес и активиране на вътрешния апоптотичен път. При меланомни клетки енаблюдавано индуциранена апоптозачрезвъншния път (Perrone et al., 2015). Куркуминът понижава експресията на антиапоптотичните протеини и повишава експресията на проапоптотични протеини като Bax, Bak, Puma, Bim и Noxa, а също и на ,„рецепторите на смъртта” Fas/CD95, TRAIL-R1/ DR4 и TRAIL-R2/DR5. Предизвиква и агрегация на Fas/CD95 без необходимост от лиганда FasL/CD95L. Куркуминът може да предизвиква освобождаване от митохондриите на фактори като цитохром $\mathrm{C}$, Smac и AIF, които задействат вътрешния апоптотичен път (Perrone et al., 2015). Куркуминът предотвратява развитието на карцином на дебелото черво при мишки, които спонтанно развиват аденоматозна полипоза поради мутация в гена $A P C$. Има данни, че куркуминът потиска пролиферацията на Helicobacter pilori, като по този начин също допринася за намаляване на вероятността за възникване на рак на стомаха. Куркуминът проявява значителна цитотоксична активност спрямо широк спектър от туморни клетъчни линии, произхождащи от: карциноми на пикочния мехур, панкреаса, простатата, шийката на матката, яйчниците, млечните жлези, белите дробове или бъбреците; невробластоми; остеосаркоми; мултиплен миелом, левкемии и др. (Perrone et al., 2015). Антинеопластичната активност на куркумина срещу целия този спектьр от различни тумори е потвърдена и при животински модели. Куркуминът не само инхибира пролиферацията на туморните клетки и индуцира апоптоза, но потиска и ангиогенезата. При мишки с рак на млечната жлеза или меланом е установено, че куркуминът намалява броя на белодробните метастази. Куркуминът намалява адхезивността на малигнените плазмоцити към СКМК (GomezBougie et al., 2015). Причината за избирателния цитотоксичен ефект на куркумина спрямо туморните клетки не е съвсем ясна, но има няколко предположения (Perrone et al., 2015). Установено е, че туморните клетки поемат повече куркумин от нормалните. Катоцяло нивата наглутатиона в туморните клетки са по-ниски. Трето, повечето туморни клетки имат конститутивна експресия на NF-кB. При плъхове е установено, че куркуминът потиска възникването на хронично алохолно увреждане на черния дроб, на белодробна фиброза под действие на циклофосфамид. Стимулира пролиферацията и диференциацията на миоцитните предшественици в напречно-набраздената мускулатура при мишки - ефект, който вероятно се дължи на потискането на NF-кB. Куркуминът ускорява зарастването на рани при опитни животни, вероятно чрез повишена продукция на TGF- $\beta 1$ и стимулиране на миграцията на фибробласти, миофибробласти, макрофаги. Установен е и блокиращ ефект на куркумина върху остеокластогенезата при ММ експериментални модели (Gomez-Bougie et al., 2015).

токсичност на куркумина при експериментални модели и при хора

Всички клинични проучвания показват, че куркуминът е изключително нетоксичен. Не е наблюдавана дозолимитираща токсичност при прием на единична доза от 12 g или при 3-месечна терапия с 8 g куркумин на ден (Burgos-Morón et al., 2010). Проучване за поносимостта на продължителен прием на 12 g куркумин всеки ден е било прекъснато, единствено защото пациентите изпитвали затруднение да поглъщат толкова голямо количество таблетки. Нужна е обаче известна предпазливост, тъй като във високи дози куркуминът има прооксидантни свойства, особено в присъствие на медни йони. При едно изследване плъхове LEC (порода, за която е характерно натрупване на мед в черния дроб и спонтанно възникване на чернодробни тумори) получавали големи дози куркумин (0,5\% от теглото на храната). Регистрирано било от 9- до 25-кратно увеличение на ДНК-адъктите в черния дроб спрямо нетретираните с куркумин животни. Продължителността на живота била намалена от 88,7 на 78,1 седмици (Jurenka, 2009). Има и данни, че куркуминът може да нарушава конформацията и функционалната активност на р53 и активно инхибира чернодробните цитохроми. Наблюдаван е хелаторен ефект по отношение на желязото при приложението на куркумин върху пльхове и последващо развитие на анемия. Изисква се повишено внимание при приложението му заедно с антукуагуланти нестероидни противовъзпалителни и други (Burgos-Morón et al., 2010).

\section{Куркумин - клинични данни}

Куркуминът достига много ниска бионаличност след перорално приложение (Gupta et al., 2013). Пикът в плазмената концентрация се наблюдава между 1 и 2 часа след приема. След еднократна доза от 2 g куркумин в плазмата се откриват само следи, а след прием на 8 g куркумин плазмената концентрация достига до около $1,77 \mu \mathrm{M}$. 
Главната причина за ниската бионаличност на куркумина е бързият му интестинален и чернодробен метаболизъм. Съвместното перорално приложение на 2 g куркумин с $20 \mathrm{mg}$ пиперин (основният алкалоид в черния пипер и силен инхибитор на лекарствения метаболизъм) осигурява 20 пьти по-висока бионаличност на куркумина, без при това да се наблюдават токсични ефекти. Основните метаболити на куркумина са тетрахидрокуркумин, хексахидрокуркумин и хексахидрокуркуминол, както итехнии на изходното вещество глюкуронидни и сулфатни конюгати. Тетрахидрокуркуминът и хексахидрокуркуминът имат значително по-ниска биологична активност от куркумина, а хексахидрокуркуминольт е лишен от такава. Преобладаващият пьт на изльчване на куркумина и метаболитите му от организма е чрез жлъчката. Друг подход за повишаване на бионаличността на куркумина е чрез прилагането му под форма на комплекс с фосфатидилхолин (Meriva ${ }^{\circledR}$ ). Доза от $450 \mathrm{mg}$ свързан куркумин осигурява сходна бионаличност с тази след приложение на 4 g свободен куркумин (Antiga et al., 2015). Проучват се и възможностите за приложение на куркумин, включен в липозоми или наночастици (Gupta et al., 2013). Проучване при пльхове показва, че в някои органи куркуминът постига по-високи концентрации, отколкото в плазмата (Gupta et al., 2013). Най-висока концентрация е измерена в червата, следвани от черния дроб, далака и бъбреците. При хора също е установено натрупване на куркумин в червата, но измерената концентрация в черния дроб е била много ниска. Данни от епидемиологични проучвания показват много пониска честота на рак на дебелото черво, млечната жлеза, панкреаса и белите дробове в страни като Индия, където консумацията на куркума е честа (Gupta et al., 2013). Дневната консумация на куркумин от средностатистическия възрастен индиец се оценява на около 80-200 mg (Bengmark et al., 2009). При клинично проучване от I фаза куркумин е прилаган перорално в дози до $8 \mathrm{~g} /$ ден в продължение на 3 месеца при пациенти с различни преканцерози. В голям брой от случаите е наблюдавано хистологично подобрение на преканцерозните лезии (Gupta et al., 2013). При друго проучване 5 пациенти с фамилна аденоматозна полипоза са лекувани в продължение на 6 месеца с куркумин $(3 \times 480 \mathrm{mg} /$ ден) и кверцетин $(3 \times 20 \mathrm{mg} /$ ден). Броят на полипите бил редуциран с $60,4 \%$, а размерът им средно с $50,9 \%$. Проведено е пилотно клинично проучване на куркумин $(2 \times 2 \mathrm{~g} /$ ден) при пациенти с моноклонална гамопатия с неизяснена значимост (Rajkumar et al., 2009). Една седмица след началото на терапията е наблюдавано понижение на серумния парапротеин при 50\% от пациентите с изходно ниво на парапротеина над $20 \mathrm{~g} / 1$. Понижението е достигало до $30 \%$ и в повечето случаи се е запазвало стабилно при проследяване в продължителност на три месеца. При пациентите с изходно ниво на парапротеина под $20 \mathrm{~g} / 1$ не е наблюдавано понижение, но не е имало и повишение през тримесечния период на проследяване. Куркумин е прилаган локално под форма на етанолен разтвор или унгвентпри пациенти с актинична кератоза, базално-клетьчен карцином или външни генитални брадавици. Постигнато е значително облекчаване на симптомите. Регистрирано е намаляване на сърбежа при почти всички пациенти и намаляване на размера на лезиите при $10 \%$. При пациенти с напреднал карцином на дебелото черво или панкреаса е наблюдавано стабилизиране на състоянието под действие на терапия с куркумин. В ход са клинични проучвания на куркумин при пациенти с карцином на дебелото черво, карцином на панкреаса, мултиплен миелом, миелодиспластичен синдром или остеосарком (Gupta et al., 2013). При клинично проучване здрави доброволци приемали по $500 \mathrm{mg}$ куркумин на ден в продължение на една седмица. Нивото на общия холестерол в серума спаднало с почти $12 \%$, нивото на HDL-холестерола се повишило с $29 \%$, а нивото на липидните пероксиди се понижило с 33\%. Тези данни предполагат възможна употреба на куркумина за превенция на артериални заболявания. Доказан е дозозависим жльчегонен ефект след еднократен прием на 20-80 mg куркумин. Най-високата доза води до 72\%-но свиване на обема на жльчния мехур два часа след приема (Gupta et al., 2013). Двойно сляпо проучване при пациенти с ревматоиден артрит показва, че доза от $1200 \mathrm{mg}$ куркумин на ден има сходна ефективност с фенилбутазон в доза от $300 \mathrm{mg} /$ ден (Gupta et al., 2013). Куркуминът (400 mg/ ден) облекчава болката и отока след операция на ингвинална херния, като в този случай сьщо има сходна ефективност с фенилбутазон (100 mg/ден). Доза от $375 \mathrm{mg}$ куркумин три пьти на ден е оказала благоприятен ефект при пациенти с различни възпалителни заболявания на очите. Установена е ефективност на куркумина при пациенти със синдром на дразнимото черво, болест на Crohn, както и при такива с улцеративен колит в остра или хронична фаза. Резултати от клинично проучване от II фаза при пациенти с язва на стомаха показват, че куркумин в доза $5 \times 500 \mathrm{mg} /$ ден реализира много 
добър терапевтичен ефект - изчезване на язвата при $48 \%$ след 4-седмично лечение и при $76 \%$ след 12-седмично лечение (Gupta et al., 2013). Много добър лечебен ефект е документиран при пациенти с псориазис, чиито лезии са третирани орален куркумин (Antiga et al., 2015). Резултати от рандомизирано контролирано проучване при бъбречно-трансплантирани пациенти показват, че комбинирана терапия с куркумин $(2 \times 480 \mathrm{mg} /$ ден $)$ и кверцетин $(2 \times 20 \mathrm{mg} /$ ден) подобрява бъбречната функция и намалява риска от отхвърляне на присадката. При популационно-базирано проучване е установено, че хора в напреднала възраст, които консумират къри често или сравнително често, показват по-добри резултати на тест за измерване на когнитивната функция от хора, които не консумират или рядко консумират подправката (Antiga et al., 2015).

\section{ЗАКЛЮЧЕНИЕ}

Куркуминът е със статут на добавка към храненето и доста често е препоръчван за повлияване на различни състояния (Lebanova et al., 2014). Многобройни изследвания обаче показват, че той има значителна противотуморна и в частност противомиеломна активност и откриват перспектива за бъдещото му приложение като лекарствен продукт. Лабилността му при орално приложение, както и потенциалните лекарствени взаимодействия с различни медикаменти, ограничават неговото свободно приложение под формата на капсулни и таблетни форми, но приемът му като подправка е показал само и единствено ползи за употребяващите го.

\section{ЛИТЕРАТУРА}

1. Antiga E, Bonciolini V, Volpi W, Del Bianco E, Caproni M. (2015). Oral curcumin (Meriva) is effective as an adjuvant treatment and is able to reduce IL-22 serum levels in patients with psoriasis vulgaris. BioMed research international, vol. 2015, Article ID 283634, 7 pages

2. Bengmark S, Mesa MD, Gil A. (2009). Plant-derived health-the effects of turmeric and curcuminoids. Nutricion hospitalaria. 24(3):273-81.

3. Burgos-Morón E, Calderón-Montaño JM, Salvador J, Robles A, López-Lázaro M. (2010). The dark side of curcumin. International journal of cancer, 126:1771-5.

4. Garcia-Gomez A, Quwaider D, Canavese M, Ocio EM, Tian Z, Blanco JF, Berger AJ, Ortiz-de-Solorzano C, HernándezIglesias T, Martens AC, Groen RW, Mateo-Urdiales J, Fraile S, Galarraga M, Chauhan D, San Miguel JF, Raje N, Garayoa M. (2014). Preclinical activity of the oral proteasome inhibitor MLN9708 in Myeloma bone disease. Clin Cancer Res, 20:1542-54.
5. Gomez-Bougie P, Halliez M, Maïga S, Godon C, Kervoëlen C, Pellat-Deceunynck C, Amiot M. (2015). Curcumin induces cell death of the main molecular myeloma subtypes, particularly the poor prognosis subgroups. Cancer Biology \& Therapy, 16(1):60-5.

6. Goel A, Kunnumakkara AB, Aggarwal BB. (2008). Curcumin as „Curcumin": from kitchen to clinic. Biochemical pharmacology, 75:787-809.

7. Gupta SC, Patchva S, Aggarwal BB. (2013). Therapeutic roles of curcumin: lessons learned from clinical trials. AAPS journal, 15(1):195-218.

8. Jurenka JS. (2009). Anti-inflammatory Properties of Curcumin, a Major Constituent of Curcuma Longa: A Review of Preclinical and Clinical Research. Alternative Medicine Review, 14(2):141-53

9. Perrone D, Ardito F, Giannatempo G, Dioguardi M, Troiano G, Lo Russo L, De Lillo A, Laino L, Lo Muzio L. (2015). Biological and therapeutic activities, and anticancer properties of curcumin (Review). Experimental and Therapeutic medicine, 10(5):1615-23.

10. Rajkumar SV. (2009). Prevention of Progression in Monoclonal Gammopathy of Undetermined Significance. Clinical Cancer Research, 15(18): 5606-8.

11. Lebanova H, Getov I, Grigorov E. (2014). Practical tool to assess reliability of web-based medicines information. Medicinski Glasnik, 11(1):221-7.

\section{Адрес за кореспонденция:}

гл. ас. маг.-фрарм. Мая Йотова, д.фр. Медицински колеж, МУ-Плевен ул. „Климент Охридски“ № 1 5803 Плевен e-mail: maya_jo@abv.bg 